\title{
Enhanced Expression of Caspase-3 in Hypertrophic Scars and Keloid: Induction of Caspase-3 and Apoptosis in Keloid Fibroblasts In Vitro
}

\author{
Yoshikiyo Akasaka, Yukio Ishikawa, Ichiro Ono, Kazuko Fujita, Takao Masuda, \\ Noriko Asuwa, Kiyoshi Inuzuka, Hideko Kiguchi, and Toshiharu Ishii
}

From the Second Department of Pathology (YA, YI, TM, HK, TI), School of Medicine, Toho University, Tokyo; the Departments of Plastic and Reconstructive Surgery (KI), and Pathology (NA), Hachioji Medical Center, Tokyo Medical College, Tokyo; Komae Branch, Bio-Science Department, Abiko Research Laboratory, Central Research Institute of Electric Power Industry (KF), and the Department of Dermatology (IO), Fukushima Medical College, Fukushima, Japan

\begin{abstract}
SUMMARY: Recent studies have suggested that the regulation of apoptosis during wound healing is important in scar establishment and development of pathological scarring. To examine the phenomenon of apoptosis and its involvement in the process of pathological scarring, we immunohistochemically quantified differential levels of expression of caspase-3 and -2 , which are activated during apoptosis in vitro, in surgical resected scar tissues. We divided 33 cases of normally healed flat scars and 18 cases of pathological scars ( 15 cases of hypertrophic scars and 3 cases of keloid) into three groups (S1 = <10 months' duration; S2 $=10$ to 40 months' duration; and S3 =>40 months' duration) according to the duration of scar. In all three groups examined, the semiquantitative scores for caspase-3 staining were significantly higher for the combination of hypertrophic scars and keloid as a group compared with normally healed flat scars, suggesting reduced cell survival and increased apoptotic cell death in hypertrophic scars and keloid. Apoptosis and caspase proteolytic activities were examined in vitro using two flat scar-derived fibroblast lines (FSFB-1 and -2) and two keloid-derived fibroblast lines (KFB-1 and -2). After 24 hours of serum deprivation, apoptotic cells were significantly increased in both KFB lines, whereas serum deprivation of FSFB-1 cells did not result in a significant increase in apoptotic cell number. After serum deprivation, significant increases in caspase-3 proteolytic activities were detected in both KFB lines compared with both FSFB lines. In contrast, no significant differences with caspase-8 activity were observed between similarly treated KFB and FSFB lines. Furthermore, serum deprivation-induced apoptosis of KFB-2 cells was significantly inhibited by the caspase-3 inhibitor Ac-Asp-Glu-Val-Asp-fluoromethyl ketone (DEVD-FMK), indicating that caspase-3 is important for serum deprivation-induced apoptosis in KFB-2 cells. Considering the role of caspase-3 as a key effector molecule in the execution of apoptotic stimuli, our results suggested that enhanced expression of caspase-3 in hypertrophic scars and keloid induces apoptosis of fibroblasts, which may play a role in the process of pathological scarring. (Lab Invest 2000, 80:345-357).
\end{abstract}

$T$ he cellular components of granulation tissue are mainly small vessels and inflammatory cells as well as fibroblasts and myofibroblasts. As the wound becomes epithelialized and the scar forms, there is a marked decrease in cellularity. Although previous studies have suggested some potential signals for elimination of the various populations of cells in tissue repair, little is known regarding the mechanisms of these cellular losses. The decrease in cell number with the various phases of healing is thought to be achieved by apoptosis (Greenhalgh, 1998). There is

\section{Received October 22, 1999.}

Sponsored by Grant-in-Aid for Scientific Research from the Ministry of Education of Japan and Project Research Grant from Toho University School of Medicine, Tokyo, Japan.

Address reprint requests to: Dr. Y. Akasaka, Second Department of Pathology, School of Medicine, Toho University, 5-21-16 Omori-Nishi, OhtaKu, Tokyo 143-8540, Japan. Fax: 8135493 5414; E-mail: akasakay@med.toho-u.ac.jp some evidence that apoptosis is involved in the regulation of wound healing in the various phases of tissue repair. In the early phases of tissue repair, Brown et al (1997) reported that inflammatory cells underwent apoptosis starting as early as 12 hours after wounding. In the later stages of tissue repair, Desmouliere et al (1995) reported that apoptosis in myofibroblasts began on Day 12 and peaked at Day 20. Wound healing must reach an equilibrium of proliferation and apoptosis to exhibit a steady-state mature scar. In contrast, extra fibroblast activity leads to an imbalance between collagen synthesis and degradation leading to excessive scar formation. The most notable pathological forms of healing are hypertrophic scarring and keloid formation. During these processes of excessive scarring, it is conceivable that apoptosis cannot take place and the cells participating in granulation tissue are not eliminated (Desmouliere et al, 1997; Rockwell et al, 1989). Previous studies have suggested a potential role of apoptosis in pathological 
forms of healing (Desmouliere et al, 1997; Greenhalgh, 1998; Rockwell et al, 1989). Although conflicting result was obtained with regard to the level of apoptosis in keloid fibroblasts (Appleton et al, 1996; Saed et al, 1998), it is still uncertain how deregulation of apoptosis can lead to hypertrophic scarring or keloid formation.

A death gene required for programmed cell death in Caenorhabitis elegans, Ced-3, shows significant similarity to the mammalian ice gene, which encodes the interleukin-1 $\beta$-converting enzymes (ICE) (Ellis and Horvitz, 1986; Yuan et al, 1993). In mammalian cells, however, multiple genes encoding ICE/Ced-3 family proteases have been cloned. To date, at least 13 members of the ICE/Ced-3 family (caspases) have been identified, the majority of which, on activation, are involved in the induction and execution phases of apoptosis (Cohen, 1997; Nicholson and Thornberry, 1997). Overexpression of various caspase family members induces apoptosis in cultured mammalian cells (Miura et al, 1993; Wang et al, 1996). Of these cysteine proteases, caspase- 3 is believed to be one of the most commonly involved in the execution of apoptosis in various cell types (Alnemri et al, 1996; Armstrong et al, 1996; Chinnaiyan et al, 1996; Enari et al, 1995). Caspases are believed to function in a hierarchy, with caspase- 8 at the apex of the cascade (Cohen, 1997). Selective inhibitors of caspases have been constructed and examined, mainly in vitro (Livingston, 1997; Nicholson et al, 1995; Shimizu et al, 1996; Talanian et al; 1997).

Although in vitro experiments revealed induction of apoptosis in the rat fibroblast line, Rat-1, by overexpression of the murine ICE gene (Miura et al, 1993), limited information is available regarding the expression of caspases and the biological significance of their expression during normal wound healing (Slomiany et al, 1998). A recent immunohistochemical study demonstrated that $\mathrm{p} 53$, bcl-2, and Fas are regionally expressed in keloid specimens (Wassermann et al, 1998), whereas there have been no studies of caspase-3 expression in hypertrophic scars or keloid. Therefore, in this study, we examined differences in immunohistochemical staining of caspase-2 and -3 in pathological scars (hypertrophic scars and keloid) versus normally healed flat scars. Furthermore, we examined the functional significance of caspase-3 using keloid-derived fibroblast lines (KFB) and flat scar-derived fibroblast lines (FSFB) in vitro. This study serves as part of an effort to further examine the phenomenon of apoptosis and its role in the deregulated process of pathological scarring.

\section{Results}

\section{Immunostaining of Caspase-3 and -2 in Normal Skin and Normally Healed Flat Scars}

In normal skin, caspase-3 expression was mainly detected in the epidermis and hair follicles. Positive cells were observed in the epidermal and dermal cells, including hair follicle epithelia and sebaceous gland epithelia (Fig. 1A). Certain endothelial cells located in the lumen of the small vessels were also positive for caspase-3 (Fig. 1C). Although the majority of fibroblasts were not immunoreactive, a small number of fibroblasts within the papillary and reticular dermis revealed detectable levels of caspase-3 expression (Fig. 1B). Caspase-3 positive fibroblasts were reduced in number in the part of immature scar tissue with poor cellularity and an increased deposit of collagen (Fig. 1C). In the dermis of normally healed flat scars, slight expression of caspase- 3 was detected in fibroblasts within thick collagen bundles, in which the fibroblast cellularity was low and most epidermal appendages were no longer visible (Fig. 2). Anti-caspase-2 antibody revealed a staining pattern that was very similar to that of anti-caspase-3 antibody, although the immunoreactivity was less intense than that with anticaspase-3 antibody.

\section{Immunostaining of Caspase-3 and -2 in Hypertrophic Scars and Keloid}

In the dermis of hypertrophic scars and keloid, abundant expression of caspase- 3 was detected in the hypercellular areas composed of aggregates of fibroblasts and small vessels (Fig. 3A). These positive cells were not uniformly distributed but appeared as clusters in which the fibroblastic cellularity was high, and nodular structures were clearly visible. The characteristic dense nodular organization of collagen fibers was clearly visible in the dermis of hypertrophic scars and keloid. Immunohistochemically, caspase-3 expression observed in fibroblasts within thick collagen bundles was more abundant in keloid lesions than in hypertrophic scars (Fig. 3B). Anti-caspase-2 antibody revealed a staining pattern that was very similar to that of anti-caspase-3 antibody, although the immunoreactivity was less intense.

\section{Immunoreactivity Scoring of Caspase-3 and -2 in Hypertrophic Scars and Keloid}

Figures 4 and 5 illustrate the immunostaining results of caspase-3 and -2 , respectively. In all three groups examined, the caspase-3 staining scores were significantly higher on average for the combination of hypertrophic scars and keloid as a group than for normal flat scars (S1, $1.9 \pm 0.5$ vs. $0.7 \pm 0.2 ; p=0.01$; S2, $1.9 \pm 0.2$ vs. $1.0 \pm 0.2, p=0.02$; S3, $1.6 \pm 0.6$ vs. $0.3 \pm 0.1, p=0.01$; Fig. 4). Similarly, with the exception of $\mathrm{S} 2$, the caspase-2 staining scores were significantly higher on average for the combination of hypertrophic scars and keloid than for normal flat scars (S1, $1.9 \pm 0.4$ vs. $0.8 \pm 0.2, p=0.01$; S3, $1,7 \pm$ 0.3 vs. $0.5 \pm 0.1, p=0.04$; Fig. 5). The average score of caspase-2 in S2 was higher for the combination of hypertrophic scars and keloid than for normal flat scars but failed to reach statistical significance (S2, $1.9 \pm 0.3$ vs. $1.4 \pm 0.2, p=0.18$; Fig. 5 ) 

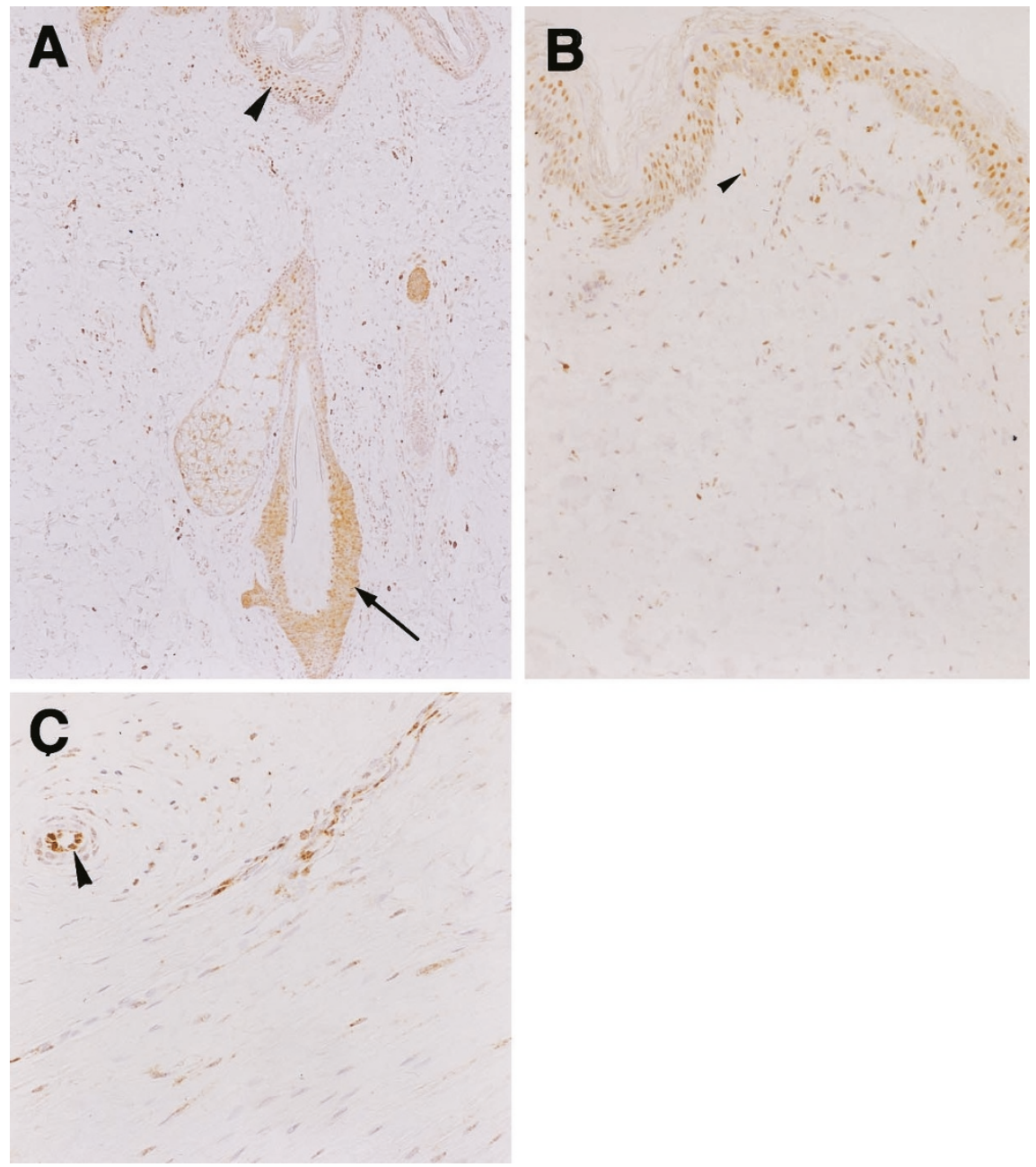

\section{Figure 1}

Immunohistochemical staining of caspase-3 in normal human skin. $A$, Immunostaining of caspase-3 is clearly visible in epidermal cells (arrowhead) and hair follicle epithelia (arrow). Sebaceous gland epithelia are also positive for caspase-3. B, A small number of fibroblasts (arrowhead) within the papillary and reticular dermis express caspase-3. C, Caspase-3 positive fibroblasts are reduced in number in the part of immature scar tissue with poor cellularity and an increased collagen deposition. Certain endothelial cells (arrowhead) located in the lumen of the small vessels are also positive for caspase-3. Original magnification: $\times 250$ in $A, \times 500$ in $B$, and $\times 400$ in $C$.

\section{Apoptosis and Proliferative Activity in Hypertrophic Scars and Keloid}

In untreated normal skin, a few terminal deoxynucleotide transferase (TdT)-mediated dUTP nick-end labeling (TUNEL) signal-positive cells were observed in the hair follicles and sebaceous glands, as described previously (Gavrieli et al, 1992; Kishimoto et al, 1997). When we examined in hypertrophic scars and keloid, certain TUNEL signal-positive fibroblasts were detected mainly in the dermis. These cells were found throughout the dermis and showed morphological changes associated with apoptosis such as the condensation of chromatin and cytoplasm (Fig. 6). On careful examination by electron microscopy, a few fibroblasts could be identified as apoptotic cells because of their highly condensed chromatin and discrete nuclear fragments (Fig. 7). Some TUNEL signalpositive cells may have been inflammatory cells because of their infiltration around blood vessels. A few TUNEL signal-positive endothelial cells were also detected.

Apoptosis and proliferative activity were evaluated by determining the number of TUNEL signal-positive cells and Ki-67 positive nuclei, respectively. In S1, the average number of TUNEL-positive cells was slightly higher for hypertrophic scars and keloid than for normal healed flat scars (S1, $1.0 \pm 0.4$ vs. $0.9 \pm 0.3$, Fig. 8). In S2 and S3, the average numbers of TUNELpositive cells were approximately threefold higher in hypertrophic scars and keloid compared with normal healed flat scars (S2, $1.0 \pm 0.3$ vs. $0.3 \pm 0.1$; S3, 1,0 \pm 0.8 vs. $0.3 \pm 0.2$, Fig. 8). Statistically, no significant difference in the number of TUNEL-positive cells was revealed between the combination of hypertrophic scars and keloid and normal healed flat scars (S1, $p=0.8$; S2, $p=0.1$; $3, p=0.3$ ). The average numbers of Ki-67-positive nuclei in the combination of hypertrophic scars and keloid and in normal healed flat scars declined in parallel with increases 


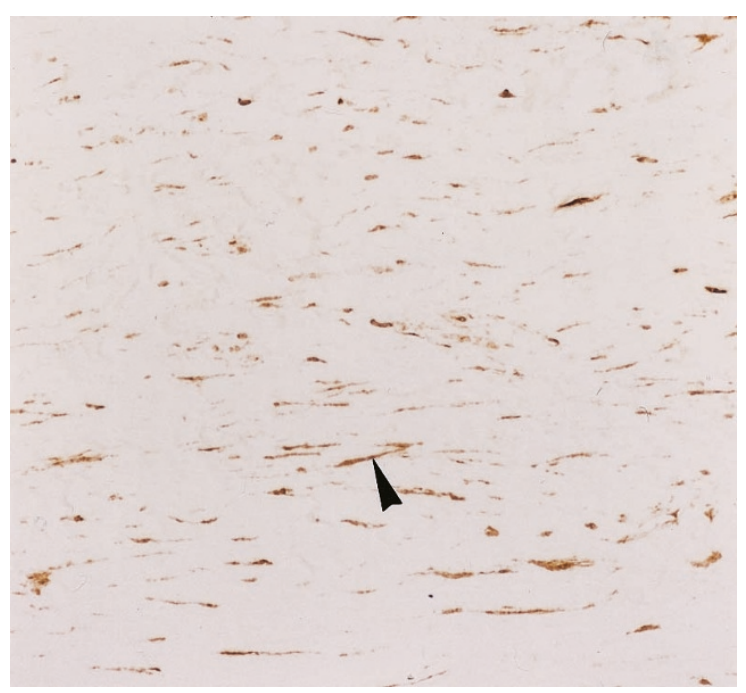

Figure 2.

Immunohistochemical staining of caspase-3 in a normally healed flat scar. In the 15-month-old scar tissue, caspase-3 expression is only barely visible in fibroblasts (arrowhead) within thick collagen bundles. Original magnification: $\times 400$.

in the duration of scar. With the exception of S2, no significant difference in the number of Ki-67positive nuclei was noted between the combination of hypertrophic scars and keloid and normal healed flat scar (S1, $23.3 \pm 6.5$ vs. $15.2 \pm 3.4, p=0.27$; S2, $12.2 \pm 2.5$ vs. $3.8 \pm 1.3, p=0.02$; S3, $3.8 \pm 3.5$ vs. $2.3 \pm 1.0, p=0.55$; Fig. 9).

\section{Establishment of Keloid-derived Fibroblast Cell Lines}

To confirm the immunostaining scores of caspase-3 in hypertrophic scars and keloid, we isolated two keloidderived cell lines (KFB-1 and -2) from two of three cases of keloid. In the original tissues obtained from these two cases, a few TUNEL signal-positive cells were detected in the dermis (Fig. 6) (mean numbers of TUNEL signal-positive cells in the original tissue of KFB-1 and -2 were 1.60 and 0.88 , respectively). No positive cells were observed in the most acellular, collagenous parts of the dermis. Our immunohistochemical analysis also revealed that many cells in both of these KFB lines showed positive cytoplasmic staining with $\alpha$-smooth muscle actin and desmin. Furthermore, many cells in both lines were generally moderately stained with 5B5 antibody (Fig. 10A), which recognizes the prolyl 4-hydroxylase $\beta$ subunit expressed on fibroblasts. These results together indicate that KFB cells have certain specific features of fibroblast (Hoyhtya et al, 1984). In addition, two FSFB lines were also stained for $\alpha$-smooth muscle actin, desmin, and by $5 \mathrm{~B} 5$ antibody. Fibroblast lines were used at passages 3 to 7 in the present study.

\section{Apoptotic Changes in Keloid-derived Fibroblasts after Serum Deprivation}

Twenty-four hours after serum deprivation, a small number of KFB-1 cells showed the typical features of apoptotic cells, characterized by nuclear fragmentation and chromatin condensation as assessed by Hoechst nuclear staining (Fig. 10B). Scoring the percentage of apoptotic cells as determined by Hoechst staining indicated that serum deprivation for 24 hours significantly increased the percentage of apoptotic cells in two KFB lines compared with that in untreated these lines (KFB-1: serum-deprived cells, $9.1 \pm 1.7 \%$; untreated cells, $1.4 \pm 0.5 \%$; $p<0.0001$; Fig. 11A) (KFB-2: serum-deprived cells, $5.6 \pm 0.4 \%$; untreated cells, $0.9 \pm 0.3 \% ; p<0.0001$; Fig. $11 \mathrm{~A}$ ), whereas no significant differences were observed in the percentage of apoptotic cells between treated and untreated cells in two FSFB lines and one normal human skin fibroblast cell line (HSFB) (Fig. 11A). Serum deprivation for 36 hours also induced a significant increase in the number of apoptotic cells in KFB-1 cells compared with similarly treated FSFB-1 and HSFB $(p<0.0001$; Fig. 11A). During the early stage of apoptosis, phosphatidylserine is translocated to the external surface of the membrane and the externalization is assessed by measuring the extent of fluorescein isothiocyanate (FITC)-annexin-V binding (Vermes et al, 1995). Scoring the percentage of apoptotic cells as determined by FITC-annexin-V binding indicated that serum deprivation for 24 hours significantly increased the percentage of apoptotic cells in two KFB lines compared with that in untreated these lines (KFB-1: serum-deprived cells, $21.9 \pm 3.4$; untreated cells, $4.5 \pm 1.1 \%$; $p<$ 0.0001 ; Fig. 11B) (KFB-2: serum-deprived cells, $18.2 \pm 0.7 \%$; untreated cells, $7.0 \pm 1.2 \% ; p<0.0001$; Fig. 11B). In contrast, no significant differences were observed in the percentage of apoptotic cells between treated and untreated cells in two FSFB lines and one HSFB line (Fig. 11B).

\section{Caspase Proteolytic Activity in Keloid-Derived Fibroblasts}

To further substantiate caspase cleavage and activation in serum deprivation-induced apoptosis of KFB lines, KFB and FSFB lines were evaluated for changes in caspase-3 and -8 proteolytic activities using an enzyme fluorometric assay. After serum deprivation, significant increases in caspase-3 proteolytic activity were detected in KFB lines, with peak values exceeding those seen in similarly treated FSFB lines and reached at 5 hours after treatment (Fig. 12A). Fivehour treatment revealed approximately 4-fold increases in caspase- 3 activity in KFB-1 cells compared with similarly treated FSFB-1 cells (Fig. 12A). In contrast, week induction of caspase-8 activity was seen in KFB- 1 cells after serum deprivation, with a peak value at 4 hours after treatment exceeding that seen in FSFB-1 cells, but no significant difference was observed in caspase-8 activity between similarly treated KFB-1 and FSFB-1 cells (Fig. 12B).

\section{Effects of Caspase Inhibitors on Caspase Activation and Apoptosis}

To obtain further evidence for the involvement of the caspase system in serum deprivation-induced apo- 

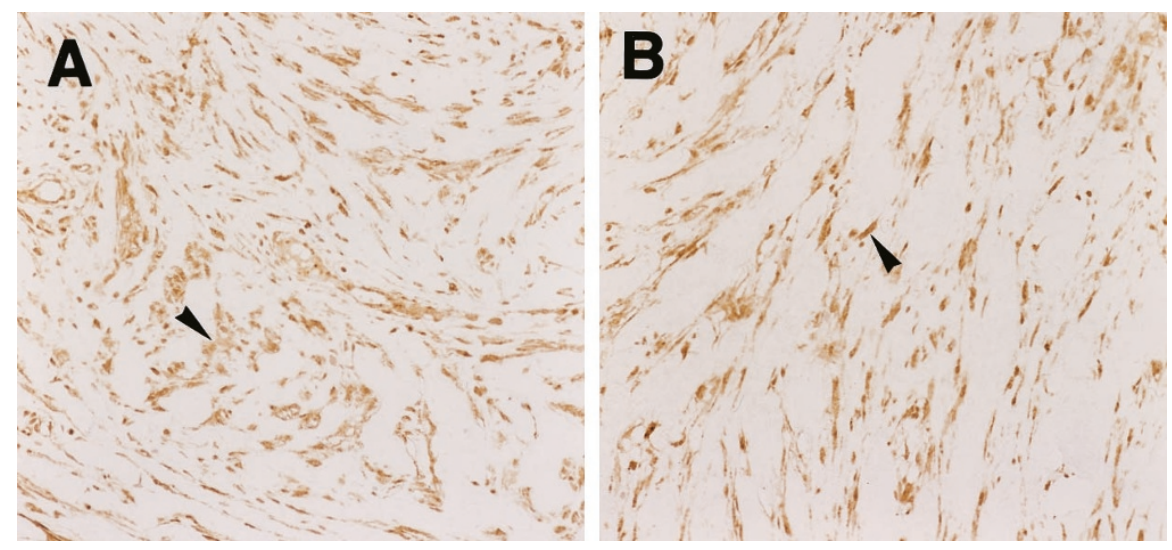

Figure 3.

Immunohistochemical staining of caspase-3 in hypertrophic scars and keloid. $A$, In the 13-month-old hypertrophic scar, abundant expression of caspase-3 is visible in the hypercellular area composed of aggregates of fibroblasts (arrowhead) and small vessels. $B$, In the 22-month-old keloid, strong expression of caspase-3 is visible in fibroblasts (arrowhead) within thick collagen bundles. Original magnification: $\times 330$ in $A$ and $\times 400$ in $B$.

\section{Semiquantitative scores for immunostaining analysis of caspase-3 expression}

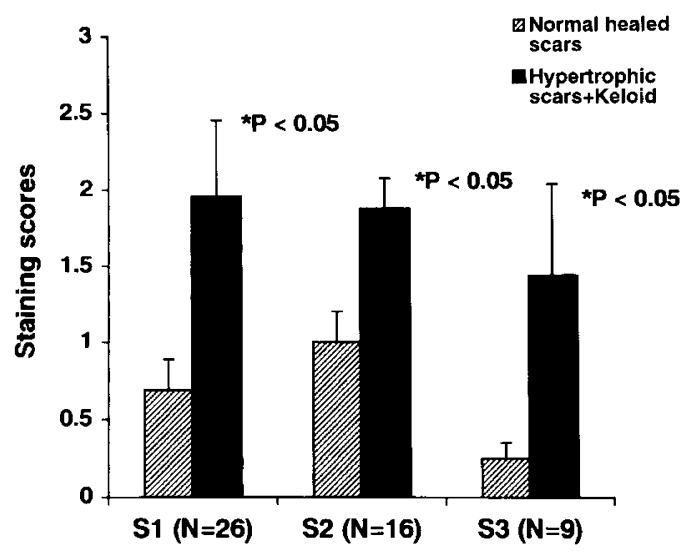

Figure 4.

Semiquantitative evaluation of caspase- 3 expression by measurement of immunostaining scores in the dermis of hypertrophic scars and keloid (closed bars) and of normal healed flat scars (hatched bars). The histograms represent the average score of caspase-3 positive cells per microscopic filed. In comparison with normal healed flat scar, the immunostaining scores of caspase- 3 are significantly increased in hypertrophic scars and keloid in all three groups ( 1 , $p=0.01$; $2, p=0.02 ; \mathrm{S} 3, p=0.01$ ). See "Materials and Methods" for details on scoring system. The numbers $(\mathrm{N})$ represent the number of scar tissue specimens examined. $p<0.05$ compared with normal healed flat scars.

ptosis of KFB cells, we tested the capacities of the caspase-3 inhibitor Ac-Asp-Glu-Val-Asp-fluoromethyl ketone (DEVD-FMK) and the caspase-8 inhibitor lleGlu-Thr-Asp-fluoromethyl ketone (IETD-FMK) to inhibit caspase activities in serum-deprived KFB-2 cells. As shown in Figure 13A, DEVD-FMK inhibited caspase- 3 activities in a dose-dependent manner, thereby confirming the specificity of the cell lysates for DEVD-FMK. In contrast, IETD-FMK did not effectively block the activity, even when used at very high concentrations (Fig. 13B). As the caspase-3 proteolytic activity was inhibited by DEVD-FMK, we next examined whether the inhibitor prevented serum derivation-

\section{Semiquantitative scores for immunostaining analysis of caspase-2 expression}

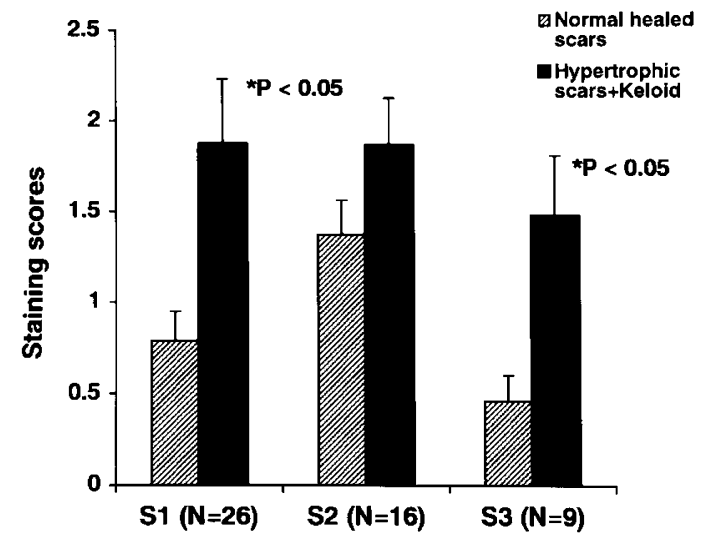

Figure 5 .

Semiquantitative evaluation of caspase-2 expression by measurement of immunostaining scores in the dermis of hypertrophic scars and keloid (closed bars) and of normal healed flat scars (hatched bars) as outlined in Figure 4. In S1 and S3, the immunostaining scores of caspase-2 are significantly increased in hypertrophic scars and keloid compared with normal healed flat scar (S1; $p=0.01, \mathrm{~S} 3 ; p=0.04)$. In S2, the average score of caspase-2 is higher for hypertrophic scars and keloid than for normal healed flat scars, but the difference is not statistically significant $(p=0.18)$. The numbers $(\mathrm{N})$ represent the number of scar tissue specimens examined. $p<0.05$ compared with that of normal healed flat scars.

induced apoptosis of KFB-2 cells. As shown in Figure 14, DEVD-FMK blocked serum deprivation-induced apoptosis of KFB-2 cells in a similar concentrationdependent manner as determined by Hoechst nuclear staining. These results suggested that serum deprivation-induced apoptosis of KFB-2 cells is mediated by caspase-3.

\section{Discussion}

Another recent study of apoptosis during burn wound healing indicated that TUNEL-positive cells were detected in two different periods: the period from the 


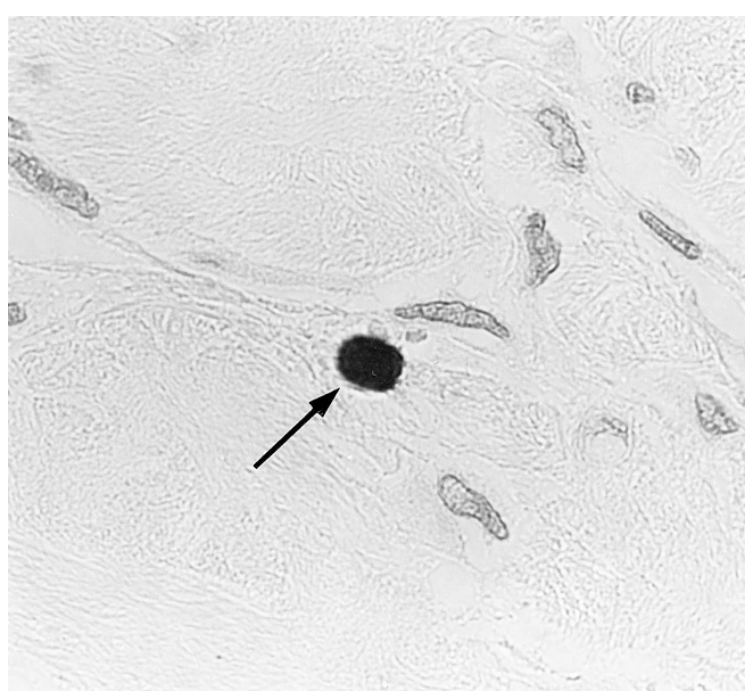

Figure 6 .

Identification of an apoptotic cell by TUNEL staining in the 14-month-old keloid. In a TUNEL-positive fibroblast undergoing apoptosis (arrow), a highly pyknotic and shrunken nucleus is visible. Original magnification: $\times 800$.

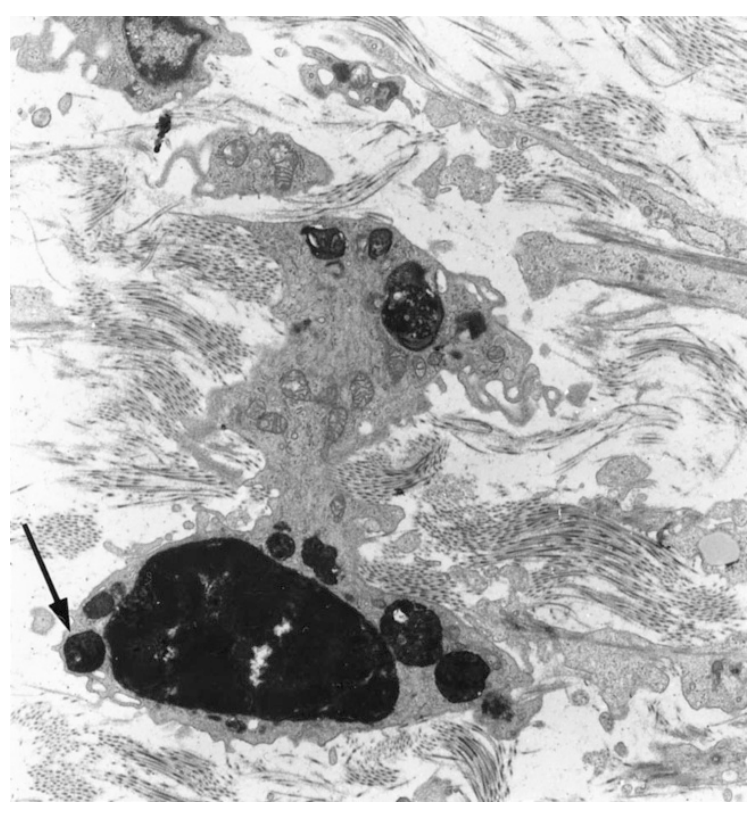

\section{Figure 7.}

Ultrastructural examination of a fibroblast undergoing apoptosis in the 22-month-old hypertrophic scar. An apoptotic fibroblast displays prominent condensed chromatin and nuclear fragmentation (arrow). Original magnification: $\times 3000$.

acute inflammatory stage to the proliferative stage and the period from the proliferative stage to the remodelling stage (Nagata et al, 1999). Although the mechanisms responsible for this phenomenon are presently unclear, we presumed that analysis of apoptosis in scar samples of widely different durations shows different levels of programmed cell death. Therefore, we divided our samples into three groups (S1, S2, and S3) according to the duration of scar after wounding. In the three groups examined, however, we revealed that the levels of caspase- 3 expression are signifi-

\section{Semiquantitative analysis for staining analysis of TUNEL positive cells}



Figure 8.

Semiquantitative evaluation of apoptosis by measurement of the number of TUNEL signal-positive cells in the dermis of hypertrophic scars and keloid (closed bars) and of normal healed flat scars (hatched bars). The histograms represent the average number of TUNEL-positive cells per microscopic filed. In S1, the average number of TUNEL-positive cells is slightly higher for hypertrophic scars and keloid than for normal healed flat scars. In S2 and S3, the average numbers of TUNEL-positive cells are approximately 3-fold higher in hypertrophic scars and keloid compared with normal healed flat scars. Statistically, no significant difference in the number of TUNEL positive cells is found between the combination of hypertrophic scars and keloid and normal healed flat scars ( $\mathrm{S} 1 ; p=0.8, \mathrm{~S} 2 ; p=0.1, \mathrm{~S} 3 ; p=0.3$ ). The numbers (N) represent the number of scar tissue specimens examined.

cantly higher in hypertrophic scars and keloid compared with normally healed flat scars. Similarly, with the exception of S2, we found that the levels of caspase-2 expression are significantly higher in hypertrophic scars and keloid compared with flat scars. The role of caspase- 3 has been known to be a key effector molecule in the execution of apoptotic stimuli in vitro (Alnemri et al, 1996; Armstrong et al, 1996; Chinnaiyan et al, 1996; Enari et al, 1995). Although the role in vivo of caspase-3 has not been determined in detail (Kuida et al, 1996; Woo et al, 1998), we postulated that the increased expression of caspase- 3 might be activated and induce a significant increase of apoptosis in hypertrophic scars and keloid. However, in S1 the number of TUNEL-positive cells is only slightly higher for the combination of hypertrophic scars and keloid than for normally healed flat scars. As reported previously, apoptosis during burn wound healing occurred during the period from the proliferative to the remodeling stage (Nagata et al, 1999). Therefore, we speculated that the relatively high number of TUNELpositive cells in normally healed flat scars of S1 reflects the presence of remodeling to some extent, which would affect fibroblasts and endothelial cells and induce an increase in their apoptosis.

In S2 and S3, no significant differences in TUNELpositive cells were detected between normally healed flat scars and the combination of hypertrophic scars and keloid as a group. There are several possible reasons for the relatively high number of apoptotic cells in normally healed flat scars of S2 and S3. One possible reason is that here we used TUNEL staining 


\section{Semiquantative analysis for staining analysis of $\mathrm{Ki}-67$ positive nuclei}

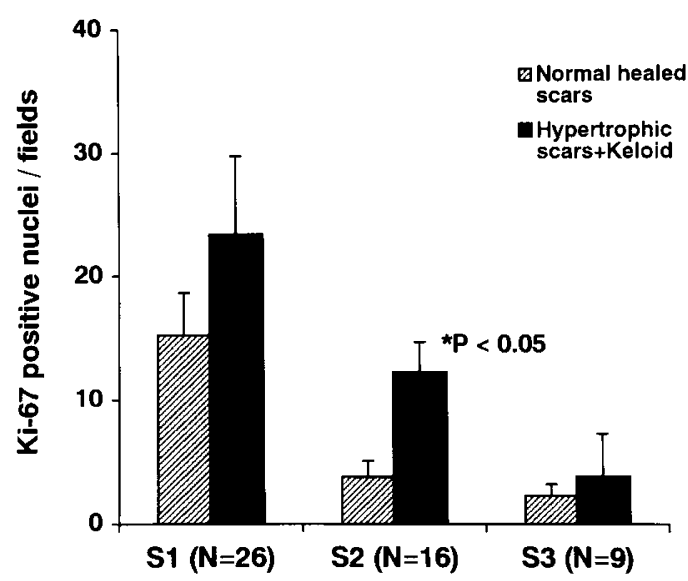

Figure 9.

Semiquantitative evaluation of proliferative activity by measurement of the number of Ki-67-positive nuclei in the dermis of hypertrophic scars and keloid (closed bars) and of normal healed flat scars (hatched bars). The histograms represent the average number of Ki-67-positive nuclei per microscopic filed. The average numbers of Ki-67-positive nuclei in the combination of hypertrophic scars and keloid and in normal healed flat scars decline in parallel with increases in the duration of the scar. With the exception of S2, no significant difference in the number of Ki-67 positive nuclei is found between the combination of hypertrophic scars and keloid and normal healed flat scars ( $\mathrm{S} 1$, $p=0.27 ; \mathrm{S} 2, p=0.02 ; \mathrm{S} 3, p=0.55)$. The numbers (N) represent the number of scar tissue specimens examined. $p<0.05$ compared with that of normal healed flat scars.

as a method for assessing apoptotic cells and identified fibroblasts undergoing apoptosis in our series of scar samples. Other cell types may be affected, notably inflammatory cells, which are difficult to identify once the process of apoptosis has occurred, which may lead to the inexact identification of the cells undergoing apoptosis. In a previous study of apoptosis in the skin, Norris (1995) suggested multiple triggers of apoptosis, which work through a variety of signaling pathways. Therefore, another possible reason is that some caspase-3-independent pathway mediates the apoptosis observed in normal healed flat scars of S2 and S3. Further studies are necessary to elucidate the signal pathway that plays critical role in induction of apoptosis during wound healing.

Previous studies showed that cultured fibroblasts often exhibit characteristics typical of their in vivo phenotypes (Calderon et al, 1996; Tuan and Nichter, 1998; Yoshimoto et al, 1999; Younai et al, 1994). Although we described higher levels of caspase-2 and -3 expression in hypertrophic scars and keloid, Wassermann et al (1998) reported that the immunostaining levels of ICE and Fas were decreased in hypertrophic scar-derived fibroblasts. Therefore, we developed two keloid-derived fibroblast cell lines (KFB-1 and -2) from two of three keloid cases, and quantified differential levels of caspase- 3 and -8 proteolytic activities between KFB and FSFB cell lines. In this study, we revealed that serum deprivation increases caspase-3 proteolytic activities in KFB cell lines, and that 5-hour treatment reveals approximately 4 -fold increases in caspase- 3 activity in KFB-1 cells compared with similarly treated FSFB-1 cells. Furthermore, 24-hour serum deprivation significantly increased the percentage of apoptotic cells in KFB-1 cells as compared with FSKB-1 cells. Although a conflicting result was obtained with regard to the level of apoptosis in keloid fibroblasts (Saed et al, 1998), our results provided evidence of a significant increase in caspase-3 proteolytic activity and apoptosis in serum-deprived keloid fibroblasts in vitro.

To further determine whether caspase-3 is a key mediator of serum deprivation-induced apoptosis of KFB cells, we pretreated each cell line with the caspase-3 inhibitor DEVD-FMK before serum deprivation. Previous studies have indicated that DEVD has specificity for caspase-3 due to its similarities to the cleavage site of the caspase- 3 substrate, PARP (Fadeel et al, 1998; Gu et al, 1995; Hasegawa et al, 1996; Izban et al, 1999; Kidd, 1998; Nicholson et al, 1995; Thornberry et al, 1997). In the present study, we have shown that the addition of DEVD-FMK after serum deprivation significantly decreases apoptosis of KFB-2, thereby confirming that caspase- 3 plays an important role in serum deprivation-induced apoptosis in KFB cells.

The question of which environmental conditions make fibroblasts susceptible to apoptosis has not been resolved. A previous study indicated that serumdeprived fibroblasts transfected with c-myc undergo apoptosis when c-myc is activated (Harrington et al, 1994). Another study indicated that $c-m y c$, rho-p21 is also a potent inducer of apoptosis, whereas $\mathrm{bcl}-2$, $\mathrm{v}$-abl, E1B, and ras prevent activation of the apoptotic pathway in fibroblasts (Jimenez et al, 1995). Recently, Ladin et al (1998) showed that clinically relevant doses of corticosteroids and interferon- $\gamma$ induce an increase in apoptosis of keloid-derived fibroblasts. Recent investigators believe that one of the triggers of apoptosis is growth factor withdrawal during differentiation (Laster et al, 1988; Moulton, 1994; Oberhammer et al, 1993; Robaye et al, 1991). This is consistent with the present results that serum deprivation significantly increases caspase-3 proteolytic activity and apoptosis in KFB lines. As homeostasis is maintained through a balance between proliferation and cell death, subtle modifications of the microenvironment may influence the beginning of fibroblast proliferation or apoptosis. This hypothesis is supported by the in vitro data by Laster et al (1988) who showed that tumor necrosis factor (TNF)- $\alpha$ induces apoptotic and necrotic forms of cell lysis. There have been no reports regarding presence of a critical inducer of apoptosis during scarring. Recently, however, Funato et al (1997) showed that basic fibroblast growth factor (bFGF) is a potential stimulator of apoptosis in rat myofibroblasts during palatal scaring. Further studies are needed to disclose the function of bFGF as an inducer of apoptosis and the relationship to caspases, the analysis of which may shed more light on apoptotic pathway during wound healing and pathological scarring. 


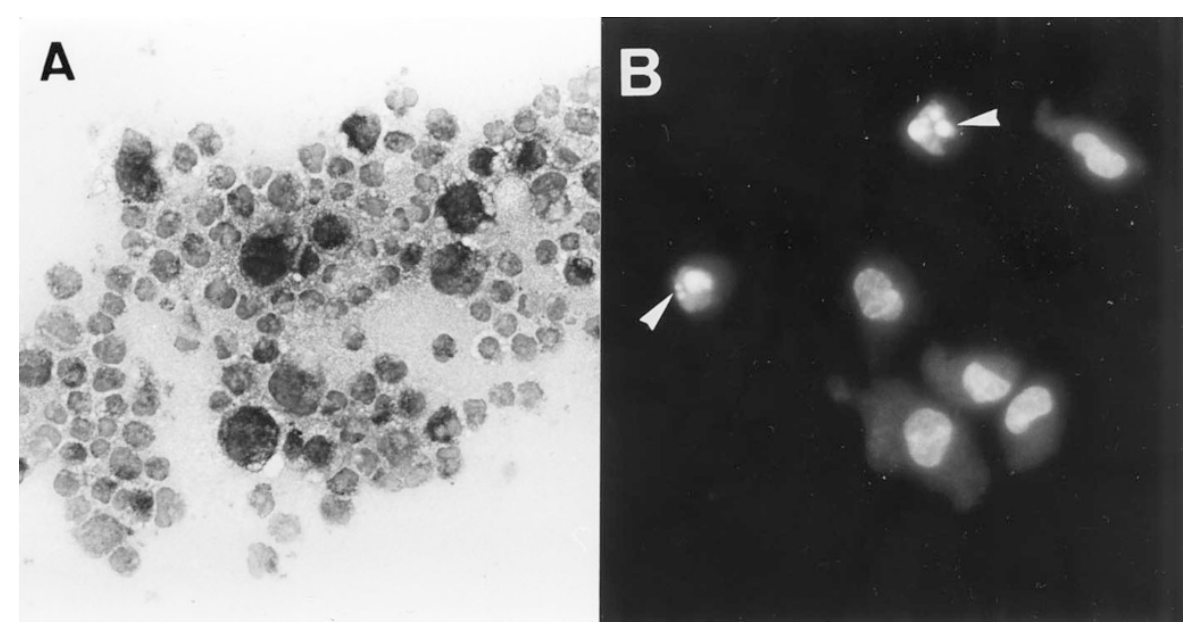

Figure 10.

A, Immunohistochemical staining on cytospin preparation of serum-deprived KFB-1 cells with $5 \mathrm{~B} 5$ antibody. KFB-1 cells after serum deprivation for 24 hours display strong cytoplasmic positive staining. $B$, Morphological changes in nuclei of serum-deprived KFB-1 cells after staining with Hoechst 33258 . KFB- 1 cells treated with serum deprivation for 24 hours show apoptotic changes with fragmented and condensed nuclei (arrowheads). Original magnification: $\times 400$ in $A$ and $\times 500$ in $B$.

\section{Materials and Methods}

\section{Patients and Tissue Samples}

A total of 51 scar samples were obtained from 47 Japanese patients ( 28 women and 19 men, mean age 29.7 years; range, 1-79 years) after undergoing surgical excision. The initial histological sections stained with hematoxylin and eosin were reviewed. Tissue sections from these specimens contained hypertrophic scar ( $n=15$, mean duration 26.2 months; range, 6-90 months), keloid ( $n=3$, mean duration 24 months; range, 8-36 months), or normally healed flat scar ( $n=33$, mean duration 47.9 months; range, 0-220 months). The hypertrophic scars or keloid were at least 6 months but less than 10 years after wounding with clinical evidence of hypertrophy including raised uniform or nodular appearance as well as erythema (Dolynchuk, 1996). The distinction in diagnosis between keloid and hypertrophic scars was made based on clinical appearance, including the tendency of keloid to persist and extend beyond the site of the original injury and the tendency of hypertrophic scars to ultimately flatten out (Tuan and Nichter, 1998). None of the patients had received previous treatment other than pressure garments in the past. None of the patients had complicating disease processes, such as diabetes mellitus, that might affect wound healing. Five untreated normal skin tissues were obtained from five different patients undergoing secondary control resection after tumor excision (3 women and 2 men, mean age 40 years). Informed consent was obtained from each subject. Our series of 51 scar specimens were divided into three groups according to the duration of scar after wounding: S1, less than 10 months' duration; S2, more than 10 months but less than 40 months; and S3 more than 40 months. Twenty-six cases (hypertrophic scar and keloid [6 cases], normally healed flat scar [20 cases]) were classified as S1 (mean duration 3.3 months); 16 cases (hypertrophic scar and keloid [9 cases], nor- mally healed flat scar [7 cases]) were classified as S2 (mean duration 22.9 months); and 9 cases (hypertrophic scar and keloid [3 cases], normally healed flat scar [6 cases]) were classified as S3 (mean duration 178.0 months). Scars were routinely fixed in $10 \%$ formalin for 7 days and embedded in paraffin. Paraffin sections (6 $\mu \mathrm{m}$ thick) were placed on Silane-Prep (Sigma, Poole, United Kingdom) slides and dried for 1 hour. Electron microscopy was performed on some scar tissues to analyze apoptotic bodies and other ultrastructural changes associated with apoptosis. Tissue samples taken from wounds were cut into $1-\mathrm{mm}$ cubes and fixed for 5 hours at room temperature in 2\% glutaraldehyde (Merck, Darmstadt, Germany) in $0.1 \mathrm{~mol} / \mathrm{l}$ cacodylate buffer. They were stained in uranyl maleate for 1 hour, postfixed in osmium tetroxide, dehydrated through a graded ethanol series, and embedded in Epon (Fluka Chemie, Buchs, Switzerland).

\section{Reagents}

The anti-caspase-3 $\quad \operatorname{lgG}_{2 a}$ monoclonal antibody (MoAb) and anti-caspase-2 $\operatorname{lgG}_{1}$ MoAb were purchased from Transduction Laboratories (Lexington, Kentucky). 5B5 MoAb and Ki-67 with the MIB-1 MoAb were obtained from Dako (Glostrup, Denmark). The caspase-3 inhibitor DEVD-FMK was purchased from Calbiochem (La Jolla, California). The caspase-8 inhibitor IETD-FMK was also obtained from Calbiochem.

\section{Immunostaining of Caspase}

Full-thickness skin and subcutaneous tissue samples were embedded in paraffin and sectioned perpendicular to the healing incision line. Sections were deparaffinized, rehydrated, and equilibrated in wash buffer solution $(0.05 \mathrm{M}$ Tris- $\mathrm{HCl}, 0.1 \%$ Tween 20 , and $0.3 \mathrm{M}$ $\mathrm{NaCl}$ ) for 30 minutes at room temperature. Endogenous peroxidase activity was quenched with $0.3 \%$ 
A Apoptotic cells assessed by Hoechst33258 staining



B Apoptotic cells assessed by Annexin V staining

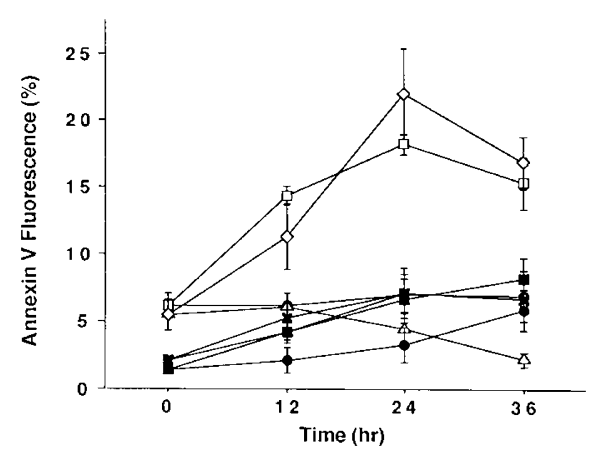

Figure 11.

Induction of apoptosis in KFB lines after serum deprivation. Apoptosis was assessed by morphological analysis of apoptotic cells after staining with Hoechst $33258(A)$ and by Annexin V $(B)$ as described in "Materials and Methods." After 24 hours of serum deprivation, significant increases in the percentage of apoptotic cell are detected in both KFB lines. In contrast, serum deprivation of FSFB-1 cells does not result in a significant increase in the percentage of apoptotic cell. Cells were cultured for the indicated times (horizontal axis, time in hours). $\diamond$, KFB-1 in the absence of $10 \%$ serum; $\square$, KFB-2 in the absence of $10 \%$ serum; $\triangle$, KFB-1 in the presence of $10 \%$ serum; O, KFB-2 in the presence of $10 \%$ serum; +, HSFB in the presence of $10 \%$ serum; $\times$, HSFB in the absence of $10 \%$ serum; $\bullet$ FSFB- 1 in the presence of $10 \%$ serum; $\mathbf{\square}$, FSFB-1 in the absence of $10 \%$ serum.

$\mathrm{H}_{2} \mathrm{O}_{2}$ in methanol for 30 minutes at room temperature. Excess proteins were blocked with $5 \%$ normal rabbit serum in wash buffer solution for 30 minutes at room temperature. The primary antibodies were diluted 1: 1000 in Tris-buffered saline (TBS) and applied for 1 hour at room temperature in a humidified chamber equilibrated with phosphate-buffered saline (PBS). Antibody staining was performed with a catalyzed signal amplification (CSA) kit (Dako) containing biotinylated rabbit anti-mouse IgG and streptavidinperoxide complex. Finally, the sections were counterstained with hematoxylin, dehydrated, and mounted with Permount (Sigma).

\section{Immunoreactivity Scoring}

Two or more sections per sample were immunohistochemically stained, and 10 to 12 randomly selected

\section{A Caspase-3 activity in fibroblast lines}

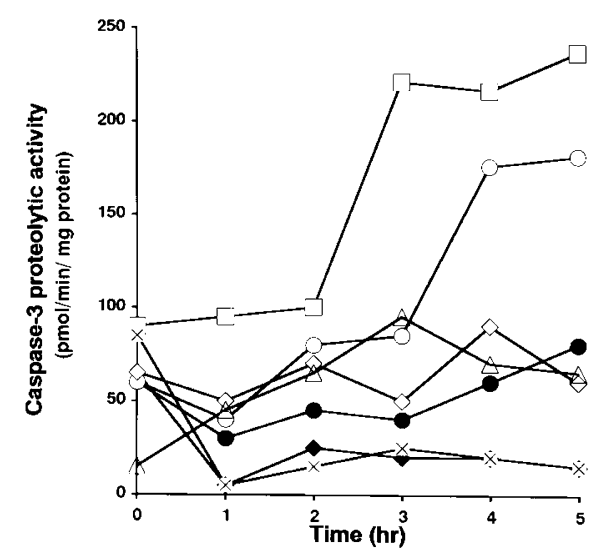

B Caspase-8 activity in fibroblast lines

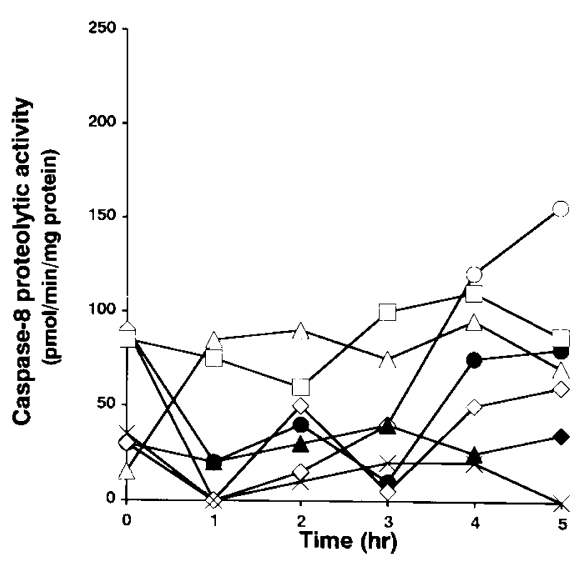

Figure 12.

Induction of caspase-3 proteolytic activity in KFB lines after serum deprivation. Proteolytic activity was measured by cleavage of the caspase-3 specific fluorogenic substrate DEVD-pNA $(A)$ or the caspase-8 specific fluorogenic substrate IETD-pNA $(B)$ as described in "Materials and Methods." Cell lysates were prepared after serum deprivation for the indicated times (horizontal axis, time in hours). Significant increases in caspase-3 proteolytic activity are detected in both KFB lines compared with both FSFB lines. Five-hour serum deprivation treatment reveals approximately 4 -fold increases in caspase-3 activity in KFB-1 cells compared with similarly treated FSFB-1 cells. In contrast, no significant difference with caspase-8 activity is observed between similarly treated KFB-1 and FSFB-1 cells. $\square$, KFB-1 in the absence of $10 \%$ serum; $\bigcirc$, KFB-2 in the absence of $10 \%$ serum; $-\mathrm{KFB}-2$ in the presence of $10 \%$ serum; $\triangle$, FSFB-1 in the absence of $10 \%$ serum; $\times$, FSFB-2 in the absence of $10 \%$ serum; $\diamond$, HSFB in the absence of $10 \%$ serum; $\diamond$, HSFB in the presence of $10 \%$ serum.

fields per section were examined at $\times 200$ magnification by an observer blind to the groups. As a positive internal control, we used caspase-positive basal epithelial cells. Immunostaining for caspase was evaluated as clear when staining was as intense as that of the positive internal control, and clearly positively stained cells were judged to be caspase-positive. According to the percentage of caspase-positive cells, immunostaining results were semiquantitatively scored as follows: 0 , when absent; $1+$, when $<10 \%$ of cells in the field were positive; $2+$, when $10 \%$ to $50 \%$ of cells in the field were positive; $3+$, when $>50 \%$ of cells in the field were stained (Pescarmona et al, 1999). Substitution of normal serum for primary antibodies, 
A Caspase-3 activity after treatment with DEVD-FMK



B Caspase-8 activity after treatment with IETD-FMK



Figure 13.

Inhibition of caspase-3 proteolytic activity by the caspase-3 inhibitor DEVDFMK. KFB-2 cells $\left(3 \times 10^{6}\right)$ were preincubated for 6 hours with various concentrations of the caspase-3 inhibitor DEVD-FMK $(A)$ or the caspase-8 inhibitor IETD-FMK $(B)$ (horizontal axis, concentration in $\mu \mathrm{M}$ ). KFB-2 cells were then incubated in the absence of $10 \%$ serum for 6 hours in the presence of each inhibitor. DEVD-FMK inhibits caspase-3 activities in a dose-dependent manner. In contrast, IETD-FMK does not effectively block the activity, even when used at very high concentrations. Proteolytic activities using extracts from the KFB-2 cells were measured as described in "Materials and Methods."

as a negative control, resulted in no staining of the cells. Immunostaining results were scored independently on separate days, and the average results were used for subsequent statistical analysis.

\section{TUNEL Reaction and Ki-67 Staining}

DNA fragmentation on paraffin sections of the scar tissue was analyzed by TUNEL with a commercial kit (Takara Co., Tokyo, Japan), according to the manufacturer's instructions. To confirm the staining specificity, the TUNEL procedure was modified as follows: as a positive control, sections were treated with 0.7 $\mathrm{mg} / \mathrm{ml}$ DNase I (Takara) in potassium cacodylate buffer ( $\mathrm{pH}$ 7.2) for 10 minutes before treatment with TdT (Takara). Negative controls included omission of TdT or biotinylated substrate from the buffer solution. Tonsil tissue was used as a positive control. Apoptotic cells showed positive staining in the nucleus. Proliferative activity was determined by immunostaining of

\section{Apoptotic cells after treatment with DEVD-FMK}

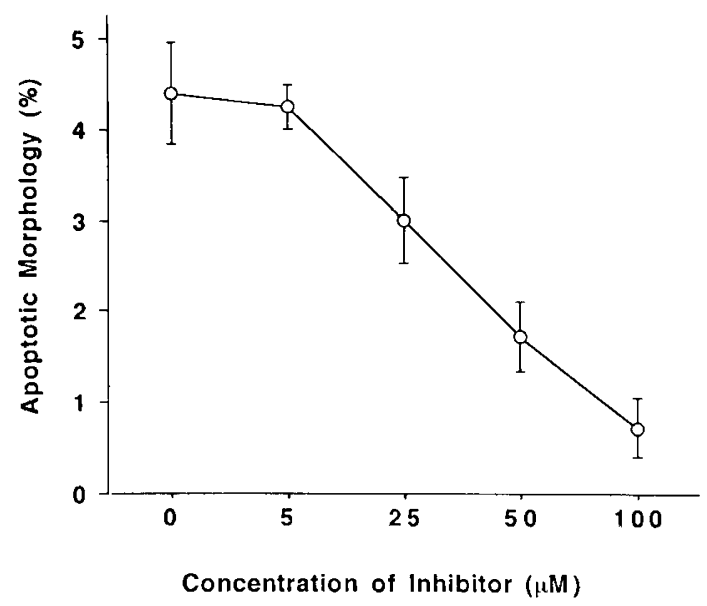

Figure 14.

Inhibition of serum deprivation-induced apoptosis of KFB-2 cells by the caspase-3 DEVD-FMK inhibitor. KFB-2 cells $\left(3 \times 10^{6}\right)$ were preincubated for 6 hours with various concentrations of DEVD-FMK (horizontal axis, concentration in $\mu \mathrm{M})$. KFB-2 cells were then incubated in the absence of $10 \%$ serum for 6 hours in the presence of the inhibitor. Apoptosis was assessed by morphological analysis after staining with Hoechst 33258. DEVD-FMK blocks serum deprivation-induced apoptosis of KFB-2 cells in a similar concentrationdependent manner.

Ki-67 on paraffin sections of the scar tissue. Immunostaining was performed with a CSA kit (Dako) as described above. Positive immunostaining for Ki-67 was almost completely confined to the nuclei. The extent of nuclei positive for TUNEL reaction or $\mathrm{Ki}-67$ staining was analyzed by microscopy at $\times 400$ magnification. Two or more sections per sample were stained, and an observer blind to the groups examined 10 to 12 randomly selected fields per section. The number of positive nuclei was calculated as the mean number of positively stained cells per field at $\times 400$ magnification, and the results were used for subsequent statistical analysis.

\section{Cell Culture}

The normal human skin fibroblast cell line, HSFB, was purchased from Technoclone GmbH (DI-709, Vienna, Austria). Two flat scar-derived fibroblast cell lines, FSFB-1 and -2, were kind gifts from Ono and coworkers (Fukushima Medical College, Fukushima, Japan). All cell lines were maintained in Dulbecco's modified Eagle's medium (DMEM; Gibco-BRL, Grand Island, New York) supplemented with $10 \%$ fetal calf serum (Gibco-BRL), 2 mmol/l glutamine (Gibco-BRL), $100 \mathrm{U} / \mathrm{ml}$ penicillin (Sigma), and $100 \mathrm{mg} / \mathrm{ml}$ streptomycin (Sigma) at $37^{\circ} \mathrm{C}$ in a humidified atmosphere containing $5 \% \mathrm{CO}_{2}$. Fibroblasts were used at passages 3 to 7 in this study. For caspase fluorometric assay, $1 \%$ trypsin solution was used to detach adherent cells. Preliminary experiments showed that trypsinization of fibroblasts undergoing apoptosis did not significantly affect the subsequent measurement 
of DEVD-p-nitroanilide (pNA) or IETD-pNA (data not shown).

\section{Hoechst Nuclear Staining and Annexin V Binding Assay in Cell Lines}

Apoptosis was assayed by staining fibroblasts with the nuclear dye Hoechst 33258 (Bisbenzimide $\mathrm{H}$ 33258 Fluorochrome, Trihydrochloride; Calbiochem) at $1 \mathrm{~mm}$. A minimum of 400 cells was scored for each sample and the percentages of apoptotic fibroblasts were determined. Viable and apoptotic cells revealed blue, round nuclei and blue fragmented nuclei, respectively. FITC-annexin $\mathrm{V}$ binding assay was performed using a commercial kit (Mebocyto Apoptosis Kit, MBL, Nagoya, Japan) from MBL (Vermes et al, 1995). A total of $1 \times 10^{6}$ cells were washed once with cold PBS ( $\mathrm{pH} 7.4)$, collected by centrifugation, and resuspended in $1 \mathrm{ml}$ of HEPES-buffered saline solution supplemented with $2.5 \mathrm{mM} \mathrm{CaCl}_{2}^{2}$ (annexin V buffer). Then, $100 \mathrm{ng}$ of annexin V-FITC and $500 \mathrm{ng}$ of propidium iodide $(\mathrm{Pl})$ were added to $100 \mathrm{ml}$ of the cell suspension $\left(1 \times 10^{5}\right.$ cells), and the mixture was incubated for 15 minutes at room temperature. Without washing, the cells were placed in $400 \mathrm{ml}$ of annexin $\mathrm{V}$ binding buffer and kept on ice until counting. Labeled cells were analyzed by fluorescence microscopy (Olympus BX-50, Tokyo, Japan) with laser excitation at $488 \mathrm{~nm}$ (reference wavelength, $530 \mathrm{~nm}$ ). For each sample, a minimum of 400 cells was examined and the number of labeled cells was counted in a blind manner. The total number of labeled cells was summed and expressed as a percentage of the total cell number.

\section{Caspase Activity in Cell Lines}

The levels of caspase activities in four cell lines were determined using a commercial fluorometric assay kit (Caspase Colorimetric Protease Assay Kit; MBL, Nagoya, Japan), according to the manufacturer's instructions (Nicholson et al, 1995). In this fluorometric assay, caspase- 3 and -8 activities were measured by cleavage of the fluorogenic substrates respective DEVD-pNA and IETD-pNA. Detached cells $\left(3 \times 10^{6}\right)$ were collected, washed three times with cold PBS, and suspended in $100 \mu \mathrm{l}$ of cell lysis buffer. Cells were incubated at $4^{\circ} \mathrm{C}$ for 10 minutes, then lysates were centrifuged at 15,000 rpm for 3 minutes, and cleared supernatants were collected. Fifty microliters of $2 \times$ reaction buffer with $10 \mathrm{mmol} / \mathrm{I}$ DTT and $5 \mu \mathrm{l}$ of 4 mmol/I DEVD-pNA substrate or IETD-pNA substrate were added to $50 \mu$ l of supernatants containing a total of $50 \mu \mathrm{g}$ of extracted proteins, followed by 1 hour of incubation in a water bath at $37^{\circ} \mathrm{C}$. A control reaction of cells treated without DEVD-pNA or IETD-pNA was included. Optical density for each specimen was determined at $405 \mathrm{~nm}$ using a plate reader (Model 550 Microplate Reader, Bio-Rad Laboratories, Inc., Hercules, California).

\section{Statistical Analysis}

Results are expressed as means \pm standard errors of the mean (SEM) unless otherwise stated. Data were analyzed by ANOVA with comparisons between groups using Fisher's least significant difference method (Snedecor and Cochran, 1980). Semiquantitative data obtained from immunohistochemical studies were expressed as median (range), and between group comparisons were analyzed using the KruskalWallis test. Analyses were performed using the Statview SE+ Graphics package (Abacus Concepts, Berkeley, California) on an Apple Power Macintosh $7600 / 132$ computer. A $p$ value less than 0.05 was considered statistically significant.

\section{Acknowledgements}

We thank Dr. Takeshi Yamada, Komae Branch, BioScience Department, Abiko Research Laboratory, Central Research Institute of Electric Power Industry for valuable discussions.

\section{References}

Alnemri ES, Livingston DJ, Nicholson DW, Salvesen G, Thornberry NA, Wong WW, and Yuan J (1996). Human ICE/CED-3 protease nomenclature. Cell 87:171.

Appleton I, Brown NJ, and Willoughby DA (1996). Apoptosis, necrosis, and proliferation: Possible implications in the etiology of keloids. Am J Pathol 149:1441-1447.

Armstrong RC, Aja T, Xiang J, Gaur S, Krebs JF, Hoang K, Bai X, Korsmeyer SJ, Karanewsky DS, Fritz LC, and Tomaselli KJ (1996). Fas-induced activation of the cell deathrelated protease CPP32 is inhibited by $\mathrm{Bcl}-2$ and by ICE family protease inhibitors. J Biol Chem 271:16850-16855.

Brown DL, Kao WW, and Greenhalgh DG (1997). Apoptosis down-regulates inflammation under the advancing epithelial wound edge: Delayed patterns in diabetes and improvement with topical growth factors. Surgery 121:372-380.

Calderon M, Lawrence WT, and Banes AJ (1996). Increased proliferation of keloid fibroblasts in vitro. J Surg Res 61:343347.

Chinnaiyan AM, Orth K, O'Rourke K, Daun H, Poirier GG, and Dixit VM (1996). Molecular ordering of the cell death pathway. $\mathrm{Bcl}-2$ and $\mathrm{Bcl}-\mathrm{XL}$ functional upstream of the CED-3-like apoptotic proteases. J Biol Chem 271:4573-4576.

Cohen GM (1997). Caspase: The executioners of apoptosis. Biochem J 326:1-16.

Desmouliere A, Redard M, Darby I, and Gabbiani G (1995). Apoptosis mediates the decrease in cellularity during the transition between granulation tissue and scar. Am J Pathol 146:56-66.

Desmouliere A, Badid C, Bochaton-Piallat ML, and Gabbiani $G$ (1997). Apoptosis during wound healing, fibrocontractive diseases and vascular wall injury. Int $\mathrm{J}$ Biochem Cell Biol 29:19-30.

Dolynchuk KN (1996). Inhibition of tissue transglutaminase and $\epsilon$ ( $\gamma$-glutamyl) lysine cross-linking in human hypertrophic scar. Wound Repair Regen 4:16-20. 
Ellis HM and Horvitz HR (1986). Genetic control of programmed cell death in the nemato de C. elegancs. Cell 44:817-829.

Enari M, Hug $\mathrm{H}$, and Nagata S (1995). Involvement of an ICE-like protease in Fas-mediated apoptosis. Nature 375: 78-81.

Fadeel B, Ahlin A, Henter JI, Orrenius S, and Hampton MB (1998). Involvement of caspases in neutrophil apoptosis: Regulation by reactive oxygen species. Blood 92:48084818.

Funato N, Moriyama K, Shimokawa H, and Kuroda T (1997). Basic fibroblast growth factor induces apoptosis in myofibroblastic cells isolated from rat palatal mucosa. Biochem Biophys Res Commun 240:21-26.

Gavrieli Y, Sherman Y, and Ben-Sasson SA (1992). Identification of programmed cell death in situ via specific labeling of nuclear DNA fragmentation. J Cell Biol 119:493-501.

Greenhalgh DG (1998). The role of apoptosis in wound healing. Int J Biochem Cell Biol 30:1019-1030.

Gu Y, Sarnecki C, Aldape RA, Livingston DJ, and Su MS (1995). Cleavage of Poly (ADP-ribose) polymerase by interleukin-1 beta converting enzyme and its homologs TX and Nedd-2. J Biol Chem 270:18715-18718.

Harrington EA, Bennett MR, Fanidi A, and Evan GI (1994). c-Myc-induced apoptosis in fibroblasts is inhibited by specific cytokines. EMBO J 13:3286-3295.

Hasegawa J, Kamada S, Kamiike W, Shimizu S, Imazu T, Matsuda H, and Tsujimoto Y (1996). Involvement of CPP32/ Yama (-like) proteases in Fas-mediated apoptosis. Cancer Res 56:1713-1718.

Hoyhtya M, Myllyla R, Piuva J, Kivirikko KI, and Tryggvason K (1984). Monoclonal antibodies to human prolyl 4-hydroxylase. Eur J Biochem 141:472-482.

Izban KF, Wrone-Smith T, Hsi ED, Schnitzer B, Quevedo ME, and Alkan S (1999). Characterization of the interleukin-1 beta-converting enzyme/ced-3-family protease, caspase-3/ CPP32, in Hodgkin's disease: Lack of caspase-3 expression in nodular lymphocyte predominance Hodgkin's disease. Am J Pathol 154:1439-1447.

Jimenez B, Arends $M$, Esteve $P$, Perona R, Sanchez R, Ramon y Cajal S, Wyllie A, and Lacal JC (1995). Induction of apoptosis in NIH3T3 cells after serum deprivation by overexpression of rho-p21, a GTPase protein of the ras superfamily. Oncogene 10:811-816.

Kidd VJ (1998). Proteolytic activities that mediate apoptosis. Annu Rev Physiol 60:533-573.

Kishimoto S, Nagata M, Takenaka $H$, Shibagaki $R$, and Yasuno H (1997). Detection of programmed cell death in anagen hair follicles of guinea pig skin by labeling of nick ends of fragmented DNA. Arch Dermatol Res 289:603-605.

Kuida K, Zheng TS, Na S, Kuan C, Yang D, Karasuyama H, Rakic P, and Flavell RA (1996). Decreased apoptosis in the brain and premature lethality in CPP32-deficient mice. Nature 384:368-372.

Ladin DA, Hou Z, Patel D, McPhail M, Olson JC, Saed GM, and Fivenson DP (1998). p53 and apoptosis alteraions in keloids and keloid fibroblasts. Wound Repair Regen 6:28-37.

Laster SM, Wood JG, and Gooding LR (1988). Tumor necrosis factor can induce both apoptic and necrotic forms of cell lysis. J Immunol 141:2629-2634.
Livingston DJ (1997). In vitro and in vivo studies of ICE inhibitors. J Cell Biochem 64:19-26.

Miura M, Zhu H, Rotello R, Hartweig EA, and Yuan J (1993). Induction of apoptosis in fibroblasts by IL-1 beta-converting enzyme, a Mammalian Homolog of the $\mathrm{C}$. elegans cell death gene ced-3. Cell 75:653-660.

Moulton BC (1994). Transforming growth factor-beta stimulates endometrial stromal apoptosis in vitro. Endocrinology 134:1055-1060.

Nagata M, Takenaka H, Shibagaki R, and Kishimoto S (1999). Apoptosis and p53 protein expression increase in the process of burn wound healing in guinea-pig skin. $\mathrm{Br} \mathrm{J}$ Dermatol 140:829-838.

Nicholson DW, Ali A, Thornberry NA, Vaillancourt JP, Ding CK, Gallant M, Gareau Y, Griffin PR, Labelle M, Lazebnik YA, Munday NA, Raju SM, Smulson ME, Yamin TT, Yu VL, and Miller DK (1995). Identification and inhibition of the ICE/ CED-3 protease necessary for mammalian apoptosis. Nature 376:37-43.

Nicholson D and Thornberry NA (1997). Caspase: Killer proteases. Trends Biochem Sci 22:299-306.

Norris DA (1995). Differential control of cell death in skin. Arch Dermatol 131:945-948.

Oberhammer F, Bursch W, Tiefenbacher R, Froschl G, Pavelka M, Purchio T, and Schulte-Hermann R (1993). Apoptosis is induced by transforming growth factor-beta 1 within 5 hours in regressing liver without significant fragmentation of the DNA. Hepatology 18:1238-1246.

Pescarmona E, Pignoloni P, Santangelo C, Naso G, Realacci M, Cela O, Lavinia AM, Martelli M, Russo MA, and Baroni CD (1999). Expression of p53 and retinoblastoma gene in highgrade nodal peripheral T-cell lymphomas: Immunohistochemical and molecular findings suggesting different pathogenetic pathways and possible clinical implications. J Pathol 188:400-406.

Robaye B, Mosselmans R, Fiers W, Dumont JE, and Galand $P$ (1991). Tumor necrosis factor induces apoptosis (programmed cell death) in normal endothelial cells in vitro. Am J Pathol 138:447-453.

Rockwell WB, Cohen IK, and Ehrlich HP (1989). Keloids and hypertrophic scars: A comprehensive review. Plast Reconstr Surg 84:827-837.

Saed GM, Ladin D, Olson J, Han X, Hou Z, and Fivenson D (1998). Analysis of p53 gene mutations in keloids using polymerase chain reaction-based single-strand conformational polymorphism and DNA sequencing. Arch Dermatol 134:963-967.

Shimizu S, Eguchi Y, Kamiike W, Matsuda H, and Tsujimoto $Y$ (1996). Bcl-2 expression prevents activation of the ICE protease cascade. Oncogene 12:2251-2257.

Slomiany BL, Piotrowski J, and Slomiany A (1998). Role of basic fibroblast growth factor in the suppression of apoptotic caspase-3 during chronic gastric ulcer healing. J Physiol Pharmacol 49:489-500.

Snedecor GW and Cochran WG (1980). Statistical Methods. lowa: lowa State University Press, 228-236.

Talanian RV, Quinlan C, Trautz S, Hackett MC, Mankovich JA, Banach D, Ghayur T, Brady KD, and Wong WW (1997). Substrate specificities of caspase family proteases. J Biol Chem 272:9677-9682. 
Thornberry NA, Rosen A, and Nicholson DW (1997). Control of apoptosis by protease. Adv Pharmacol 41:155-177.

Tuan T-L and Nichter LS (1998). The molecular basis of keloid and hypertrophic scar formation. Mol Med Today 4:19-24.

Vermes I, Haanen C, Steffens-Nakken H, and Reutelingsperger C (1995). A novel assay for apoptosis. Flow cytometric detection of phosphatidylserine expression on early apoptotic cells using fluorescein labelled Annexin V. J Immunol Methods 184:39-51.

Wang S, Miura M, Jung YK, Zhu H, Gagliardini V, Shi L, Greenberg AH, and Yuan J (1996). Identification and characterization of Ich-3, a member of the interleukin-1 beta converting enzyme (ICE)/Ced-3 family and upstream regulator of ICE. J Biol Chem 23:20580-20587.

Wassermann RJ, Polo M, Smith P, Wang X, Ko F, and Robson MC (1998). Differential production of apoptosismodulating proteins in patients with hypertrophic brun scar. J Surg Res 75:74-80.
Woo M, Hakem R, Soengas MS, Duncan GS, Shahinian A, Kagi D, Hakem A, McCurrach M, Khoo W, Kaufman SA, Senaldi G, Howard T, Lowe SW, and Mak TW (1998). Essential contribution of caspase 3/CPP32 to apoptosis and its associated nuclear changes. Genes Dev 12:806-819.

Yoshimoto $\mathrm{H}$, Ishihara $\mathrm{H}$, Ohtsuru A, Akino K, Murakami R, Kuroda H, Namba H, Ito M, Fujii T, and Yamashita S (1999). Overexpression of insulin-like growth factor-1 (IGF-1) receptor and the invasiveness of cultured keloid fibroblasts. Am J Pathol 154:883-889.

Younai S, Nichter LS, Wellisz T, Reinisch J, Nimni ME, and Tuan TL (1994). Modulation of collagen synthesis by transforming growth factor-beta in keloid and hypertrophic scar fibroblasts. Ann Plast Surg 33:148-151.

Yuan J, Shaham S, Ledoux S, Ellis HM, and Horvitz HR (1993). The C. elegans cell death gene ced-3 encodes a protein similar to mammalian interleukin-1 beta-converting enzyme. Cell 75:641-652. 